\title{
Response of Leaf Functional Traits of Cerasus yedoensis (Mats.) Yü Li to Serious Insect Attack
}

\author{
Congyan Wang*, Jun Liu, Hongguang Xiao, Daolin Du** \\ Institute of Environment and Ecology, School of the Environment and Safety Engineering, \\ Jiangsu University, \\ Zhenjiang 212013, P. R. China
}

Received: 11 August 2015

Accepted: 22 October 2015

\begin{abstract}
The morphological features of plants, such as leaf functional traits, are adaptations that enable them to live under different environmental conditions. Thus, leaf functional traits can provide a link between various environmental factors and leaf functions. This study aims to gain insights into the differences in leaf functional traits between healthy (no insect attack) and damaged (serious insect attack) Cerasus yedoensis Yü li. Petiole diameter, leaf length, leaf thickness, ratio of leaf length to petiole length, leaf shape index, and single leaf wet and dry weight of damaged leaves were significantly higher than those of healthy leaves, but lower for leaf moisture and specific leaf area (SLA). Plasticity indices of petiole diameter, petiole length, leaf length, leaf width, and leaf shape index of healthy leaves were higher than those of damaged leaes, but contrary for the plasticity indices of the ratio of leaf length to petiole length, leaf moisture, and SLA of healthy leaves. SLA was positively correlated with leaf moisture but negatively correlated with petiole diameter, leaf length, leaf thickness, ratio of leaf legth to petiole length, leaf shape index, and single leaf wet and dry weight. After serious insect attack, damaged C. yedoensis contained increased quantities of material investment per unit area to exhibit a more efficient anti-herbivore defense; thus, leaf moisture and SLA were decreased, but leaf thickness, and single leaf wet and dry weight were increased. Meanwhile, damaged leaves also were more slender and invested more biomass to the lamina than to the petiole.
\end{abstract}

Keywords: healthy leaves, damaged leaves, insect attack, specific leaf areas, Cerasus yedoensis

\section{Introduction}

Morphological characteristics determine how plants capture resources, thereby affecting the success of one

*e-mail: liuyuexue623@163.com

**e-mail: ddl@ujs.edu.cn species when competing with other species for resources [1-2]. Plants live in a changing environment; as such, plants should cope with and adapt to changes, such as pest attacks (e.g., by aphids). Life behaviors of plants are also associated with acquired resources (including space resources and nutrient resources). Thus, optimum life history patterns and biomass allocation trade-offs of plants are closely related to individual resource acquisition and 
individual fitness advantages because resource is one of the most important environmental factors affecting plants [3-4].

Leaves are one of the most important plant organs as they capture the light required for plant development, growth, and survival [5-6]. Leaves exhibit phenotypic plasticity in response to changes in environmental factors to help plants improve fitness; with phenotypic plasticity, plants can utilize a successful ecological strategy in changing environments during life processes [2, 7-9]. In addition to phenotypic plasticity, specific leaf area (SLA, defined as investment per unit of light capture surface deployed) can indicate the adaptability of plants to different habitats; as such, SLA is a key functional trait reflecting the trade-off between resource capture and conservation (e.g., high SLA can indicate high resource acquisition and use efficiency with low investment in leaf construction and protective tissues according to the leaf economic spectrum) [7-8, 10-11]. Furthermore, leaf size, leaf thickness, leaf shape index (calculated as the ratio of leaf length to leaf width), single leaf dry weight, and leaf moisture are important indices of leaf functional traits because these indices can be used as indicators of resourceuse strategy of plants [2, 7-8]. Under normal conditions, leaf functional traits may withstand the effects of many intrinsic and extrinsic factors, such as light intensity, soil physiochemical properties, soil nutrient contents (particularly nitrogen), temperature, and precipitation [2, 6-8].

Cerasus yedoensis Yü li is a widely used ornamental plant in China; this species was first observed, two thousand years ago in Qin and Han dynasties of the ancient Chinese sages [12-13]. Unfortunately, C. yedoensis is vulnerable to pest attacks (such as aphids). Thus, this study was conducted using cross-site comparisons to describe the differences in leaf functional traits of healthy (no insect attack) and damaged (serious insect attack) $C$. yedoensis. Leaf functional traits, including leaf size, leaf thickness, ratio of leaf length to petiole length, leaf shape index, single leaf wet and dry weight, leaf moisture, and SLA of healthy and damaged C. yedoensis were assessed to provide insights into the ontogenetic strategy of C. yedoensis attacked by insects to different degrees (i.e., no attack and serious attack). In this study, the following hypotheses were presented:

1) Leaf moisture and SLA of damaged leaves may be lower than those of healthy leaves; by contrast, leaf thickness, and single leaf wet and dry weight of damaged leaves may be higher than those of healthy leaves because damaged leaves should invest great biomass on leaf structures per unit area to exhibit a highly efficient anti-herbivore defense under seriuos insect attack. Furthermore, thick leaves or leaves with denser tissues contained greater dry biomass per unit area and lower SLA levels than thin leaves [14-15].

2) Damaged leaves may display a higher phenotypic plasticity in leaf functional characteristics (SLA, as the preferred agent of plant growth and defense strategies) $[7-8,10-11]$ than healthy leaves to develop a highly efficient anti-herbivore defense; this result could occur because the enhanced phenotypic plasticity for any functional characteristic could benefit plants by allowing these organisms to maximize fitness in the environment $[16,17]$.

3 Leaf thickness, and single leaf wet and dry weight were negatively correlated with SLA; by contrast, leaf size and leaf moisture were positively correlated with SLA because leaves with high SLAs provide low structural investment, but leaves with low SLAs likely invest great biomass on leaf structures [2, 7-8, 11, 15].

\section{Materials and Methods}

\section{Experimental Design}

C. yedoensis samples with different degrees of insect attack (i.e., no attack and serious attack) were obtained from two sampling sites in Zhenjiang, P. R. China (samples with no attack and serious attack were respectively collected from $32^{\circ} 21^{\prime} \mathrm{N}, 119^{\circ} 51^{\prime} \mathrm{E}$ and $32^{\circ} 20^{\prime} \mathrm{N}, 119^{\circ}$ $52^{\prime} \mathrm{E}$ ) in June 2014. The degree of insect attack was determined on the basis of external leaf characteristics. In particular, leaves that were not attacked by insects were green, bright, and energetic without insect spots; leaves that were seriously attacked by insects were yellow, rough, and wilted with many insect spots. A total of 20 plant samples from each site were collected to determine plant characteristics. In one plant sample, five adult and intact leaves were selected randomly to determine the functional traits. The samples were collected from public land; as such, no specific permissions were required to obtain samples from these locations, and details on why these areas were chosen were unnecessary. Ethical approval to conduct this study was not required because no animals considered in any animal welfare regulation were handled or collected; furthermore, no endangered or protected species were involved in sampling or experiments.

\section{Determination of Plant Characteristics}

The characteristics related to plant performance and fitness were determined. Mean petiole diameter and leaf thickness were calculated using a Vernier caliper with an accuracy of $0.01 \mathrm{~mm}$.

Leaf shape index was calculated as the ratio of leaf length to the corresponding leaf width [18-19]. Leaf length is the maximum value along the midrib, and width is the maximum value perpendicular to the midrib [19]. Leaf length and leaf width were measured using a ruler.

The ratio of leaflength to petiole length was determined using the ratio of the leaf length to the corresponding petiole length. Petiole length was measured using a ruler.

Leaf moisture was calculated by subtracting leaf dry weight from leaf wet weight; the difference was then divided by leaf wet weight. Single leaf dry weight was obtained by initially subjecting the samples to oven drying at $60^{\circ} \mathrm{C}$ for $24 \mathrm{~h}$ to achieve a constant weight; final single 

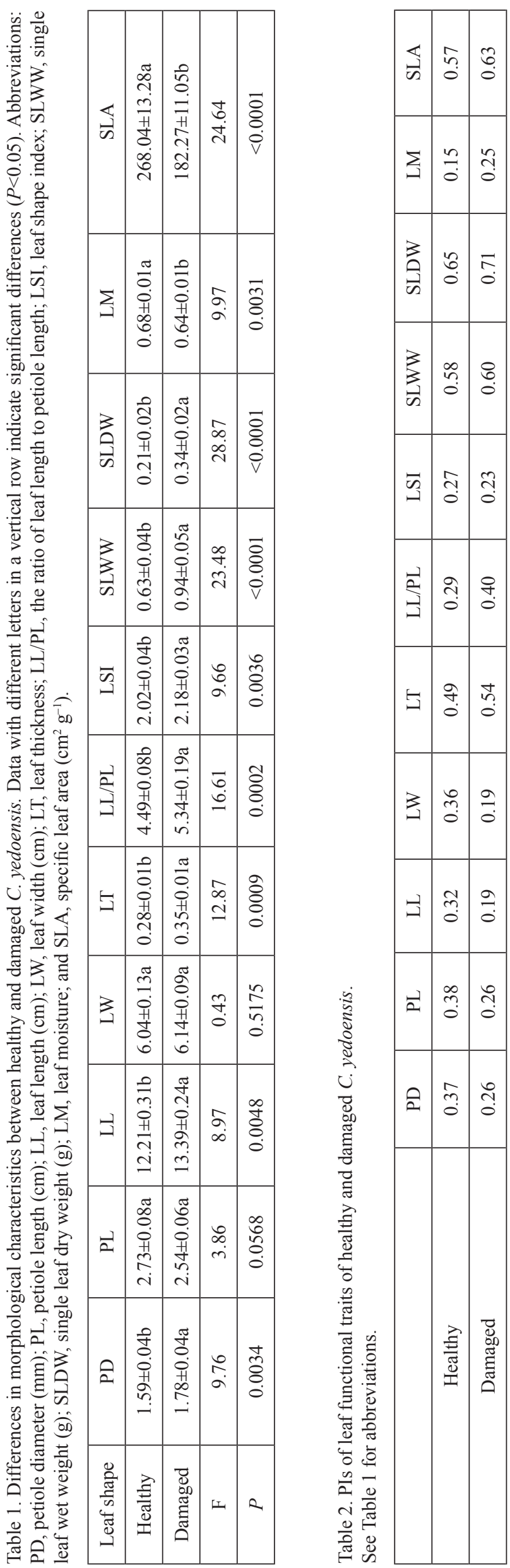

leaf dry weight was then determined using an electronic balance with an accuracy of $0.001 \mathrm{~g}$.

To estimate SLA, 10 leaf discs with a definite area per leaf of individual plant from adult and intact leaves were collected by using a borer with a definite diameter. The main leaf veins were carefully avoided during coring to reduce sample variation. The collected leaf discs were stored in small parchment bags, transported to the laboratory $12 \mathrm{~h}$, and oven-dried at $60^{\circ} \mathrm{C}$ for $24 \mathrm{~h}$ to obtain a constant weight demined by using by an electronic balance with an accuracy of $0.001 \mathrm{~g}$. SLA was calculated by dividing leaf area by the corresponding leaf dry weight $\left(\mathrm{cm}^{2} \mathrm{~g}^{-1}\right)[10,20]$.

The plasticity indices (PIs) [this index ranged from 0 (no plasticity) to 1 (maximum plasticity)] of the morphological characteristics of $C$. yedoensis with different degrees of insect attack were calculated according to previously described methods [21-22].

\section{Statistical Analysis}

Data were evaluated to determine the deviations from normality and homogeneity of variance before data analysis. Differences among various dependent variables were assessed using analysis of variance. One-way ANOVA was applied to evaluate the effects of the degrees of insect attack on the morphological characteristics of $C$. yedoensis with different degrees of insect attack. Statistically significant differences were set at $P$ values equal to or lower than 0.05 . Patterns among various dependent variables were determined by correlation analysis using SPSS (version 17.0).

\section{Results}

A significant difference was observed between the morphological characteristics of $C$. yedoensis with different degrees of insect attack. Petiole diameter, leaf length, leaf thickness, ratio of leaf length to petiole length, leaf shape index, and single leaf wet and dry weight of damaged leaves were significantly higher than those of healthy leaves (Table $1, P<0.01$ ); by contrast, leaf moisture and SLA of damaged leaves were significantly lower than those of healthy leaves (Table $1, P<0.01$ ). Other indices were not significantly different between damaged and healthy leaves (Table $1, P>0.05$ ).

The PIs of petiole diameter, petiole length, leaf length, leaf width, and leaf shape index of healthy leaves were higher than those of damaged leaves (Table 2). By contrast, the PIs of the ratio of leaf length to petiole length, leaf moisture, and SLA of healthy leaves were lower than those of damaged leaves (Table 2). The PIs of other indices were not significantly different between damaged and healthy leaves (Table 2).

Correlation patterns among morphological characteristics of healthy and damaged $C$. yedoensis were observed. In particular, petiole diameter was also positively correlated with leaf length, leaf width, leaf thickness, 


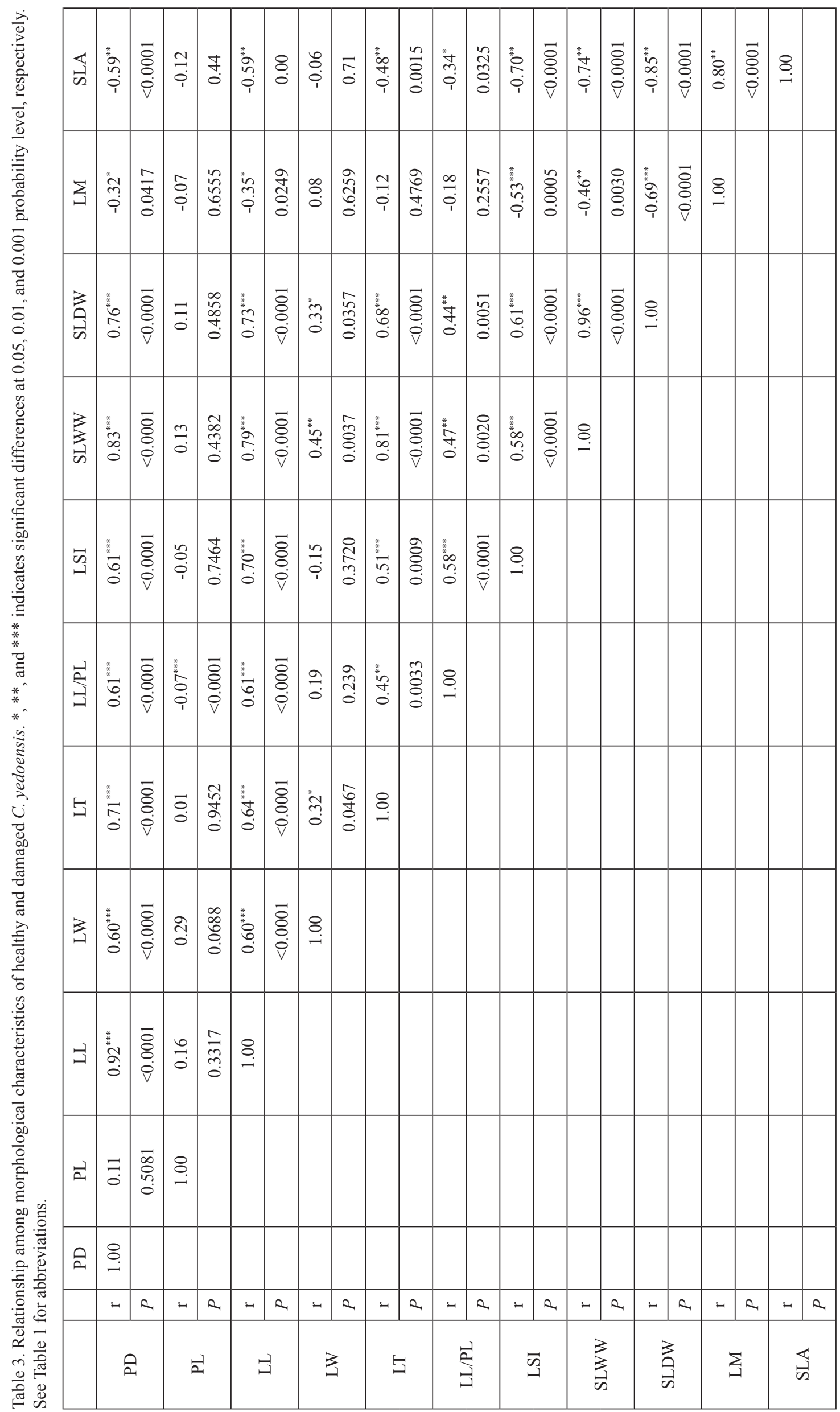


ratio of leaf length to petiole length, leaf shape index, and single leaf wet and dry weight (Table $3, P<0.01$ ), but negatively correlated with leaf moisture and SLA (Table $3, P<0.05)$. Petiole length was negatively correlated with the ratio of leaf length to petiole length (Table 3, $P$ $<0.01)$. Leaf length was positively correlated with leaf width, leaf thickness, ratio of leaf length to petiole length, leaf shape index, and single leaf wet and dry weigh (Table $3, P<0.01$ ), but negatively correlated with leaf moisture and SLA (Table 3, $P<0.05$ ). Leaf width was positively correlated with leaf thickness, and single leaf wet and dry weight (Table 3, $P<0.05$ ). Leaf thickness was positively correlated with the ratio of leaf length to petiole length, leaf shape index, and single leaf wet and dry weigh (Table $3, P<0.01$ ), but negatively correlated with SLA (Table $3, P<0.01)$. The ratio of leaf length to petiole length was positively correlated with leaf shape index, and single leaf wet and dry weigh (Table $3, P<0.01$ ), but negatively correlated with SAL (Table 3, $P<0.05$ ). Leaf shape index was negatively correlated with single leaf wet and dry weigh (Table $3, P<0.01$ ), but negatively correlated with leaf moisture and SLA (Table $3, P<0.01$ ). Single leaf wet weight was positively correlated with single leaf dry weight (Table $3, P<0.01$ ) but negatively correlated with leaf moisture and SLA (Table $3, P<0.01$ ). Single leaf dry weight was negatively correlated with leaf moisture and SLA (Table 3, $P<0.01$ ). Leaf moisture was positively correlated with SLA (Table 3, $P<0.01$ ).

\section{Discussion}

Plants struggle to develop an optimal and successful ecological strategy of the trade-off between various morphological characteristics to maximize resources and exhibit fitness advantage in changing environments. For instance, plants adapt to multivariate environments by changing morphological characteristics and growth mechanisms [2, 6, 8-9]. One of the most commonly regarded key traits of plant development strategies is SLA (trade-off between resource capture and conservation); SLA is also a critical trait in carbon fixation of plants $[7,8,10-11]$. In general, leaves with high SLAs require low structural investments and high growth rates but low resistibility; by contrast, leaves with low SLAs likely invest great biomass on leaf structures with high resistibility but low growth rate $[2,7,8,11]$. Thus, after a serious insect attack occurred, damaged C. yedoensis contained larger quantities of material investment per unit area to perform a highly efficient anti-herbivore defense underrious insect attack. This high material investment per unit area is necessary to yield low leaf moisture and SLA, but high leaf thickness, single leaf wet weight, and single leaf dry weight compared with the results described in previous studies [7, 14-15]. Furthermore, leaves with low SLA contain more ructural carbohydrates, such as lignin and cellulose in their cell walls, than those with high SLA [23]. Consistent with the first hypothesis, our results showed that leaf moisture and SLA of damaged leaves were significantly lower than those of healthy leaves. Leaf thickness, and single leaf wet and dry weight of damaged leaves were significantly higher than those of healthy leaves. This result indicated that $C$. yedoensis invested more biomass on resistance structure per unit area to develop a highly efficient anti-herbivore defense under serious insect attack. Moreover, the results of the present study also showed that petiole diameter, leaf length, the ratio of leaf length to petiole length, and leaf shape index of damaged leaves were significantly higher than those of healthy leaves. This result indicated that $C$. yedoensis invested more biomass in leaf lamina than in leaf petiole; C. yedoensis leaf also became more slender after this plant was seriously attacked by insects. A significant allometric scaling relationship was observed between leaf petiole and leaf lamina [24]. Leaf petiole exhibited an enhanced robustness to allow leaves to gain weight and adapt to the altered resource allocation pattern.

Morphological characteristics that contribute fitness advantage to plants in natural environments are under selection pressure; phenotypic plasticity should be a potential target of selection $[8,16]$. Thus, functionally adaptive plasticity in allocation, morphological, and physiological traits involved in resource acquisition may play a key role in successful survival $[8,16]$ because plants with enhanced phenotypic plasticity for any functional characteristic can maximize fitness in multivariate environments [8, 16-17]. Therefore, the morphological characteristics of $C$. yedoensis, which exhibits phenotypic plasticity to a certain extent, could be implicated in local adaptation of plants to multivariate environments, such as those exposed to different degrees of insect attack. For instance, damaged leaves may display high phenotypic plasticity in leaf functional characteristics (e.g., SLA) to achieve a successful survival chance under serious insect attack. Our study further revealed how the range of phenotypic plasticity of leaf functional traits differed between healthy and damaged $C$. yedoensis. In particular, damaged leaves showed higher phenotypic plasticity in the ratio of leaf length to petiole length, leaf moisture, and SLA than in other parameters. Although these results are partly consistent with the second hypothesis, our results showed that healthy leaves exhibited higher phenotypic plasticity in petiole diameter, petiole length, leaf length, leaf width, and leaf shape index than in other parameters. Therefore, the phenotypic plasticity of healthy leaves could be observed mainly in the changes in leaf size (leaf length and leaf width as indicators). The phenotypic plasticities of leaf moisture and SLA of damaged leaves were higher thn those of healthy leaves, possibly because $C$. yedoensis should invest more biomass in resistance structure per unit area than in other parameters to develop a highly efficient anti-herbivore defense under serious insect attack. The phenotypic plasticity of the ratio of leaf length to petiole length of damaged leaves increased because $C$. yedoensis invested more biomass to leaf lamina compared with leaf petiole; this increase in phenotypic plasticity could then increase weight leaf to allow plants to adapt to the altered resource allocation pattern. 
Under normal conditions, leaves with high SLA, which allocate less biomass in leaf construction to yield high resource acquisition and use efficiency, may show lower leaf thickness, and single leaf wet and dry weight but higher leaf size and leaf moisture than leaves with low SLA $[7,8,11,16]$. Our results showed that SLA was positively correlated with leaf moisture but negatively correlated with petiole diameter, leaf length, leaf thickness, ratio of leaf length to petiole length, leaf shape index, and single leaf wet and dry weight. This result indicated that SLA could be influenced by many other leaf functional traits, such as leaf length, leaf thickness, leaf shape index, single leaf wet and dry weight, and leaf moisture. This result is consistent with that described in previous studies [7, 16]. However, our results are only partly consistent with the third hypothesis because SLA was negatively related to leaf size. The negative relationship between SLA and leaf size may be attributed to the fact that species with larger leaves have diminishing returns on the biomass they invest in light capture and that there should be run-away selection for species with smaller leaves [25]. Empirical studies have also provided conflicting results, in which leaf size and SLA show positive [26-27], negative [25, 28], unrelated [29], or variable correlations between habitats [30]. These varying results suggest that correlations between leaf functional traits are species-specific. SLA is also negatively related to leaf thickness, and this result is consistent with the general pattern of low SLA associated with high leaf thickness [7, 31]. Conversely, this negative relationship is not consistent with previous results [32]. As one of the most variable plant characteristics affecting major physiological properties that enable plants to adapt to numerous environmental conditions [9, 33], such as defense against pathogens [23] and herbivores [9], leaf shape index was positively correlated with petiole diameter, leaf length, leaf thickness, ratio of leaf length to petiole length, ad single leaf wet and dry weight, but negatively correlated with leaf moisture. Therefore, leaf shape index may be affected by leaf length, leaf thickness, allocated biomass in leaf lamina relative to leaf petiole (the ratio of leaf length to petiole length), a single leaf wet and dry weight (although leaf shape index was calculated as the ratio of leaf length to the corresponding leaf width). SLA decreased significantly as leaf shape index increased [34]. Moreover, petiole diameter was positively related to leaf length, leaf width, leaf thickness, and single leaf wet and dry weight. This result indicated that an allometric relationship may be observed between petioles; furthermore, the costs of supporting leaf petiole possibly increased as leaf lamina increased. This result is also consistent with that in a previous study [24]. Hence, an inverse effect could be observed among the morphological characteristics of plants.

In summary, plants should develop an optimal and successful ecological strategy. For instance, plants may achieve balance between resource acquisition and resistance, particularly in stressful environments; thus, plants could maximize resources and develop a fitness advantage in changing environments [35].

\section{Acknowledgements}

This study was supported by the National Natural Science Foundation of China (31300343, 31570414), the Natural Science Foundation of Jiangsu Province, China (BK20130500), Universities Natural Science Research Project of Jiangsu Province, China (13KJB610002), and the Research Foundation for Advanced Talents, Jiangsu University (12JDG086). The funders had no role in study design, data collection and analysis, the decision to publish, or preparation of the manuscript. We are grateful to the anonymous reviewer for the insightful and constructive comments that greatly improved this manuscripy.

\section{References}

1. SCHARFY D., FUNK A., VENTERINK H.O., GUSEWELL $\mathrm{S}$. Invasive forbs differ functionally from native graminoids, but are similar to native forbs. New Phytologist. 189, 818, 2011.

2. SOUDZILOVSKAIA N.A., ELUMEEVA T.G., ONIPCHENKO V.G., SHIDAKOV I.I., SALPAGAROVA F.S., KHUBIEV A.B., TEKEEV D.K., CORNELISSEN J.H.C. Functional traits predict relationship between plant abundance dynamic and long-term climate warming. Proceedings of the National Academy of Sciences of the United States of America. 110, 18180, 2013.

3. REN M.X., ZHANG Q.G. The relative generality of plant invasion mechanisms and predicting future invasive plants. Weed Research. 49, 449, 2009.

4. WANG L., WANG C.Y., XIAO H.G., SHI Y.C., ZHANG F., ZHAO L.L., DU D.L. Insights into the reproductive allocation strategy of different invasive plants. American Journal of Biology and Life Sciences. 2, 12, 2014.

5. LIU F.D., YANG W.J., WANG Z.S., XU Z., LIU H., ZHANG M., LIU Y.H., AN S.Q., SUN S.C. Plant size effects on the relationships among specific leaf area, leaf nutrient content, and photosynthetic capacity in tropical woody species. Acta Oecologica. 36, 149, 2010.

6. MENG F.Q., CAO R., YANG D.M., NIKLAS K.J., SUN S.C. Trade-offs between light interception and leaf water shedding: a comparison of shade- and sun-adapted species in a subtropical rainforest. Oecologia. 174, 13, 2014.

7. WRIGHT I.J., REICH P.B., WESTOBY M., ACKERLY D.D., BARUCH Z., BONGERS F., CAVENDER-BARES J., CHAPIN F.S., CORNELISSEN J.H.C., DIEMER M., FLEXAS J., GARNIER E., GROOM P.K., GULIAS J., HIKOSAKA K., LAMONT B.B., LEE T., LEE W., LUSK C., MIDGLEY J.J., NAVAS M-L., NIINEMETS Ü., OLEKSYN J., OSADA N., POORTER H., POOT P., PRIOR L., PYANKOV V.I., ROUMET C., THOMAS S.C., TJOELKER M.G., VENEKLAAS E., VILLAR R. The worldwide leaf economics spectrum. Nature. 428, 821, 2004.

8. POORTER H., NIINEMETS U., POORTER L., WRIGHT I.J., VILLAR R. Causes and consequences of variation in leaf mass per area (LMA): a meta-analysis. New Phytologist. 182, 565, 2009.

9. CAMPITELLI B.E., SIMONSEN A.K., WOLF A.R., MANSON J.S., STINCHCOMBE J.R. Leaf shape variation and herbivore consumption and performance: a case study with Ipomoea hederacea and three generalists. ArthropodPlant Interactions. 2, 9, 2008. 
10. SCHEEPENS J.F., FREI E.S., STÖCKLIN J. Genotypic and environmental variation in specific leaf area in a widespread Alpine plant after transplantation to different altitudes. Oecologia. 164, 141, 2010.

11. PIETSCH K.A., OGLE K., CORNELISSEN J.H.C., CORNWELL W.K., BÖNISCH G., CRAINE J.M., JACKSON B.G., KATTGE J., PELTZER D.A., PENUELAS J., REICH P.B., WARDLE D.A., WEEDON J.T., WRIGHT I.J., ZANNE A.E., WIRTH C. Global relationship of wood and leaf litter decomposability: the role of functional traits within and across plant organs. Global Ecology and Biogeography. 23, 1046, 2014.

12. SONG A.C., SUN Y.H., LIU Y.H., LIANG Y., ZHANG N., WANG K., DONG L. Comprehensive evaluation of ornamental values of Cerasus in Beijing. Journal of Northwest Forestry University. 29, 201, 2014 [In Chinese].

13. SONG H.Z., WAND I.H., YU X.N. Cherry culture and its application in garden in China and Japan. Journal of Hunan Agricultural University (Social Sciences Edition). 36, 98, 2010 [In Chinese].

14. SHIPLEY B., VILE D., GARNIER E., WRIGHT I.J., POORTER H. Functional linkages between leaf traits and net photosynthetic rate: reconciling empirical and mechanistic models. Functional Ecology. 19, 602, 2005.

15. OSNAS J.L.D., LICHSTEIN J.W., REICH P.B., PACALA S.W. Global leaf trait relationships: Mass, area, and the leaf economics spectrum. Science. 340, 741, 2013.

16. MCINTYRE P.J., STRAUSS S.Y. Phenotypic and transgenerational plasticity promote local adaptation to sun and shade environments. Ecology and Evolution. 28, 229, 2014.

17. SULTAN S.E. Promising directions in plant phenotypic plasticity. Perspectives in Plant Ecology, Evolution and Systematics. 6, 227, 2004.

18. JEONG N., MOON J.K., KIM H.S., KIM C.G., JEONG S.C. Fine genetic mapping of the genomic region controlling leaflet shape and number of seeds per pod in the soybean. Theoretical and Applied Genetics. 122, 865, 2011.

19. WANG Z., ZHANG L. Leaf shape alters the coefficients of leaf area estimation models for Saussurea stoliczkai in central Tibet. Photosynthetica. 50, 337, 2012.

20. KARDEL F., WUYTS K., BABANEZHAD M., VITHARANA U.W.A., WUYTACK T., POTTERS G., SAMSON R. Assessing urban habitat quality based on specific leaf area and stomatal characteristics of Plantago lanceolata L.. Environmental Pollution. 158, 788, 2010.

21. CHEN L.Y., TIU C.J., PENG S.L., SIEMANN E. Conspecific plasticity and invasion: invasive populations of Chinese tallow (Triadica sebifera) have performance advantage over native populations only in low soil salinity. PLoS ONE. 8, e74961, 2013.

22. LAMARQUE L.J., PORTÉ A.J., EYMERIC C., LASNIER J.-B., LORTIE C.J., DELZON S. A test for pre-adapted phenotypic plasticity in the invasive tree Acer negundo L.. PLoS ONE. 8, e 74239, 2013.

23. MEDIAVILLA S., GARCIA-CIUDAD A., GARCIA-CRIADO B., ESCUDERO A. Testing the correlations between leaf life span and leaf structural reinforcement in 13 species of European Mediterranean woody plants. Functional Ecology. 22, 787, 2008.

24. LI G.Y., YANG D.M., SUN S.C. Allometric relationships between lamina area, lamina mass and petiole mass of 93 temperate woody species vary with leaf habit, leaf form and altitude. Functional Ecology. 22, 557, 2008.

25. NIKLAS K.J., COBB E.D., NIINEMETS Ü., REICH P.B., SELLIN A., SHIPLEY B., WRIGHT I.J. "Diminishing returns" in the scaling of functional leaf traits across and within species groups. Proceedings of the National Academy of Sciences of the United States of America. 104, 8891, 2007.

26. ACKERLY D.D., KNIGHT C.A., WEISS S.B., BARTON K., STARMER K.P. Leaf size, specific leaf area and microhabitat distribution of chaparral woody plants: contrasting patterns in species level and community level analyses. Oecologia. 130, 449, 2002.

27. BURNS K.C., BEAUMONT S.A.M. Scale-dependent trait correlations in a temperate tree community. Austral Ecology. 34, 670, 2009.

28. MILLA R., REICH P.B. The scaling of leaf area and mass: the cost of light interception increases with leaf size. Proceedings of the Royal Society of London Series B. 274, $2109,2007$.

29. WRIGHT I.J., ACKERLY D.D., BONGERS F., HARMS K.E., IBARRA-MANRIQUEZ G., MARTINEZ-RAMOS M., MAZER S.J., MULLER-LANDAU H.C., PAZ H., PITMAN N.C.A., POORTER L., SILMAN M.R., VRIESENDORP C.F., WEBB C.O., WESTOBY M., WRIGHT S.J. Relationships among ecologically-important dimensions of plant trait variation in seven neotropical forests. Annals of Botany. 99, 1003, 2007.

30. PICKUP M., WESTOBY M., BASDEN A. Dry mass costs of deploying leaf area in relation to leaf size. Functional Ecology. 19, 88, 2005.

31. REICH P.B., WALTERS M.B., ELLSWORTH D.S. From tropics to tundra: global convergence in plant functioning. Proceedings of the National Academy of Sciences of the United States of America. 94, 13730, 1997.

32. BATTIE-LACLAU P., LACLAU J.-P., BERI C., MIETTON L., MUNIZ M.R.A., ARENQUE B.C., DE CASSIA PICCOLO M., JORDAN-MEILLE L., BOUILLET J.-P., NOUVELLON Y. Photosynthetic and anatomical responses of Eucalyptus grandis leaves to potassium and sodium supply in a field experiment. Plant, Cell and Environment. 37, 70, 2014.

33. CAMPITELLI B.E., STINCHCOMBE J.R. Natural selection maintains a single-locus leaf shape cline in Ivyleaf morning glory, Ipomoea hederacea. Molecular Ecology. 22, $552,2013$.

34. PAN F.J., SUN Y.J., ZHANG D.N., ZENG D.J., XU G.P., HUANG Y.Q. Plant specific leaf areas of Cyclobalanopsis glauca-Pteroceltis tatarinowii community in karst region, northern Guangx. Guihaia. 33, 295, 2013. (In Chinese)

35. XIAO H.G., WANG C.Y., LIU J., WANG L., DU D.L. Insights into the differences in leaf functional traits of heterophyllous Syringa oblata under different light intensities. Journal of Forestry Research. 26, 613, 2015. 